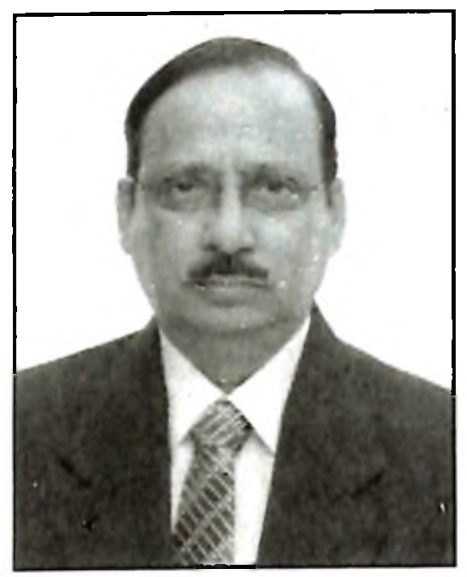

\title{
From Hony. Secretary General Desk
}

Dear Members,

The $63^{\text {rd }}$ Annual Assembly and International Conference of the International Institute of Welding (IIW) were held at the Swissotel, The Bosporus Hotel, Istanbul from $11^{\text {th }}$ to $16^{\text {th }}$ July, 2010. You will be happy to know that this is the first time that a delegation of as many as 35 members from IIW-India attended the meetings of different technical commissions and the working groups during the Assembly and Conference. 695 Delegates ( 533 for the Assembly and 131 for the Conference along with 19 young professionals) from $\mathbf{4 8}$ countries attended these events.

During the Assembly we had a very fruitful discussions with AWS officials for mutual co-operation in promoting IIW-2011 to be held in India \& IIW-2012 to be held in the USA.

The International Institute of Welding has chosen us to organize the prestigious $64^{\text {th }}$ Annual Assembly and International Conference, which will be held in Chennai during $17^{\text {th }}$ to $22^{\text {nd }}$ July, 2011. Concurrently, "Weld India-2011" - the 6 $^{\text {th }}$ International Welding Technology Exhibition will also be held. An Organizing Committee headed by Mr. R. Ravi, International Advisory Committee headed by Dr. Baldev Raj and National Advisory Committee headed by Mr. A K Mukherjee have also been set up. The entire event will be organized jointly by 3 Preparatory Committees viz. Assembly Preparatory Committee from Kolkata, Conference Preparatory Committee from Mumbai and Exhibition Preparatory Committee from Chennai. All these committees have already started their activities in full swing. This is the first time IIW-India is organizing this mega event and to make this a grand success I need your whole hearted support and co-operation.

The successful running of any Institute depends on its members and how happy and satisfied they are with the functioning of the Institute. This will automatically lead to greater involvement, commitment and a sense of ownership by the members to the Institute's activities. With a view to improving our services to the members and response to potential members, the G P Committee has taken a number of initiatives for rendering more services to the members.

The one-day National Weld Meet (NWM-2010) is being held on Friday, the $6^{\text {th }}$ August, 2010 at Hotel The Sunway GRT Grand at Puducherry, Chennai on the theme," Recent Advances in Welded Fabrication".

The $44^{\text {th }}$ Annual General Meeting of the Institute will be held at Kolkata on $25^{\text {th }}$ September' 10 . I on behalf of the Central Council, cordially invite you all to attend the AGM.

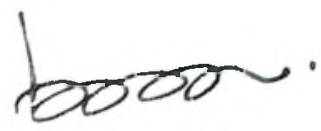

PARIMAL BISWAS

E-mail : parimalbiswas.iiw@gmail.com

09831052652 